\title{
The Planning and Architecture of Deportation, Imprisonment and Death - Reflections on the Ethical Implications of the Holocaust for Built and Natural Environment Disciplines
}

\author{
Richard Kötter \\ Senior Lecturer in Economic /Political Geography \\ Department of Geography and Environmental Sciences \\ School of the Built and Natural Environment \\ Faculty of Engineering and Environment \\ Northumbria University \\ Lewis Preston \\ Formerly Senior Lecturer in Architecture \\ School of the Built and Natural Environment \\ Northumbria University \\ Newcastle upon Tyne, NE1 8ST.
}

\begin{abstract}
This paper is based on an exchange and dialogue between two academics on how the legacy of the Nazi period is relevant for built environment, planning and human geography disciplines. We argue that we should be reflecting on the conduct and utility of spatial and urban planning and design in the Nazi period from the perspective of professional ethics, not just as a historical reflection and remembrance but also to inform current and future generations of professionals.
\end{abstract}

Keywords: National Socialist (NS / Nazi) spatial planning and urban design; professional conduct and ethics, Holocaust / Shoah / Porajnos ${ }^{1}$, ,tabula rasa“; Oswiecim / Auschwitz; German occupation of Poland from 1939. ${ }^{2}$

\subsection{Architecture and Planning, Post-Auschwitz'?}

Taking their cue from Adorno“s text on „education after Auschwitz“ in the 1960s ${ }^{3}$, a whole series of professions have asked this question for their respective field: what do the events of Auschwitz (as the central symbolic reference space) and the genocide in Europe more broadly perpetrated by Nazi Germany and her collaborateurs mean for the actors of the following generations ? ${ }^{4}$ We shall restrict ourself to a consideration (informed by historiographies) of the disciplines of architecture and urban construction (Rose, 1993, Gutschow, 2001; Willems, 2000), spatial planning and urban design (Rössler, 1989 and 2001, in Szöllösi-Janze, M. (ed); Steinweis, 1994; Schmals, ed, 1997;

\footnotetext{
${ }^{1}$ Holocaust is often used as the global overarching term (from the Greek Holokauston, meaning a burnt sacrifice to a god), since the 19th century used to describe large-sale disasters, and used widesprad since the 1950s and increasingly to refer to the descrution of the Jews in distinction to the remainder of he Genocide by many but by no means all scholars or the public, whilst Shoah is the distinctive Jewish term, meaning calamity or catastrophe. Porajnos is the distinctive Sinti and Roma term for the „Gypsy“ Holocaust, an event they call the "Devouring". See McDonough \& Cochrane, J. (2008): The Holocaust, page 1, footnote 1. Palgrave Macmillan: Basingstoke; Gilbert, M (1985): The Holocaust. Holt, Rinehart \& Winston.

${ }^{2}$ We will use for historical and contemporary reasons BOTH the original or assigned Polish and German place-names of localities in this paper.

${ }^{3}$ see Adorno, T., "Education After Ausschwitz“, in: Critical Models: Interventions and Catchwords, 191 pp. Columbia University Press, New York.

${ }^{4}$ see, for instance, Bauman, Z. (1989): Modernity and the Holocaust. Polity Press: Bristol; Burleigh, M. (1997): Ethics and Exterminations: Reflections on Nazi Genocide. Cambridge University Press; Roth, J.K. (1999): Ethics after the Holocaust: Reflections, Critiques, and Responses. Paragon House Publishers; Roth, J.K. (2007): Ethics During and After the Holocaust: In the Shadow of Birkenau. New edition. Palgrave Macmillan: Basingstoke; Geddes, J.L. et. al. (eds)(2009): The Double Bind of Ethics after the Holocaust. Salvaging the Fragments. Palgrave Macmillan: Basingstoke; Mineau, A. (1999): Making of the Holocaust: Ideology and Ethics in the Systems Perspective. Rodopi B.V.Editions.
} 
DFG, 2006; Marcus, 2007) and geography (Bassin, 1987; Sandler, 1988; Fahlbusch et. al, 1989; Kost, 1989; and more recent research by Charlesworth et. al, 2006; Stenning et. al, 2008), applied geography and ethnography (Blackbourn, 2006, 2009 in Nelson; Hagen \& Ostergren, 2006) and cartography, representation and propaganda (Herb, 1997; Hagen, 2004, 2006, 2008) - though clearly there are numerous and intrinsic connections to logistics 5 , adminstration ${ }^{6}$, finance ${ }^{7}$, industry and business ${ }^{8}$, engineering, design and construction ${ }^{9}$, and information sciences and management ${ }^{10}$, embedded in their political and cultural context at the time ${ }^{11}$, - to name but a few on which this kind of reflection and research has been undertaken. ${ }^{12}$ Middle-level managers also have their Place in this, as an extension of active and ideologically convinced collaborators, on ,pragmatic and applied' career paths, and as by-standers also of course (Allen, 1997).

${ }^{5}$ see, for instance, Cesarini, D. (2006): Eichmann: His Life and Crimes. New edition. Vintage: London; Ahrendt, H. (1963): Eichmann in Jerusalem - see the Penguin extracts in 2005 unde the title Eichmann and the Holocaust; Rutherford, P. T. (2007): Prelude to the final solution: the Nazi program for deporting ethnic Poles, 1939-1941. University of Kansas Press; Flyer "Special Trains to Death - Deportations with Deutsche

Reichsbahn",http://www.deutschebahn.com/site/bahn/en/group/history/topics/special_trains_to__death/special_trains_to _death.html; Engwert, A. \& Kill, S. (eds)(2007): Sonderzüge in den Tod. Die Deportationen mit der Deutschen Reichsbahn. Böhlau Verlag: Wien; Gottwaldt \& Schulle (2005): Die „Judendeportationen aus dem Deutschen Reich 1941-1945. Eine kommentierte Chronologie. Marix Verlag: Wiesbaden; Adler, H-G. (1974): Der Verwaltete Mensch. Studien zur Deportation der Juden aus Detschland. Tuebingen; Black, E. (2009): Nazi Nexus: America's Corporate Connections to Hitler's Holocaust. Dialog Press [including on General Motor's motorisation of the German army]; Rosh, L. \& Jaeckel, E. (eds)(1999): Der Tod ist ein Meister aus Deutschland. Deportation und Ermordung der Juden. Hoffman und Campe Verlag: Hamburg; Hilberg, R. (1976):, 'German Railroads, Jewish Souls', in: Society 14, Nr. 1, pp. 60-74.Hilberg, R. (1981): Sonderzuege nach Auschwitz. Mainz;

6 Baxtor, I. (2008): The Commandant: Rudolf Höss, the creator of Auschwitz. Maverick House: Dublin;

Allen, MT (2008): The Banality of Evil Reconsidered: SS Mid-Level Managers of Extermination Through Work, Central European History, CUP; Spring, T.E. (1999): The Nazi resettlement bureacracy and the Baltic states of Estonia and Latvia. University of Wisconsin Press: Madison.

7 e.g. James, H. (2004): The Nazi Dictatorship and the Deutsche Bank. Cambridge University Press: Cambridge.

8 Hayes, P. (2000): Industry and Ideology: I. G. Farben in the Nazi Era, $2^{\text {nd }}$ edition. Cambridge University Press; Lindner, S.H. (2008): Inside IG Farben: Hoechst During the Third Reich. Cambridge University Press; Jeffreys, D. (2010): Hell's Cartel: IG Farben and the Making of Hitler's War Machine. Holt McDougal;

Hayes, P. (2007): From Cooperation to Complicity: Degussa in the Third Reich. Cambridge University Press; Setkiewicz, P. (2008): The Histories of Auschwitz IG Farben Werk Camps 1941-1945. Auschwitz-Birkenau State Museum: Oswiecim; Tooze, A. (2006): The Wages of Destruction. The Making and Breaking of the Nazi Economy. Routledge: London.

9 for instance, see Gutman, Y \& Berenbaum, M. (eds)(1994): Anatomy of the Auschwitz Death Camp. Indiana University Press: Bloomington; Swiebocka, T. (2001): The Architecture of Crime: The "Central Camp Sauna" in Auschwitz-Birkenau. Auschwitz-Birkenau State Musuem: Oswiecim; Swiebocka, T. (ed)(2008): The Architecture of Crime: The Security and Isolation System of the Auschwitz Camp. Auschwitz Birkenau State Museum: Oswiecim; Piper, F. \& Swiebocka, T. (eds)(2005): Auschwitz. Nazi Death Camp (translation: Selvage, D.). Auschwitz-Birkenau State Museum: Oswiecim; Schüle, A. (2010): Industrie und Holocaust: Topf \& Söhne - Die Ofenbauer von Auschwitz. Wallstein Verlag Gmbh: Göttingen.

${ }^{10}$ Black, E. (2008): IBM and the Holocaust: The Strategic Alliance Between Nazi Germany and America's Most Powerful Corporation. Dialog Press. According to Black, the Third Reich, embarking upon conquest and genocide, needed enabling technological solutions, step by step, from the identification and cataloguing programmes of the 1930s to the selections of the 1940s since only after Jews were identified could they be targeted for swift asset confiscation, the creation of ghettos, deportations, enslaved labour and, ultimately, annihilation, in an automated and systematic fashion. Punch-card technology was available widely in Europe, but the author argues that IBM technology organised nearly everything in Germany and then Nazi-ocupied Europe (through intermediaries in Geneva, and its German subsidiary Dehomag), from the identification of the Jews in censuses, registrations, and ancestral tracing programmes to the running of railways and organising concentration camp registration, custom-designing and tailoring the complex applications and solutions one by one; not merely sell the machines, but leasing and servicing them for high fees and becoming the sole source of the billions of punch-cards the NSstate needed. Dehomag are shown to have trained Nazi officers, including concentration camp administrators, to use the IBM devices and their custom-designed applications.

11 see Jeffrey, H. (1993): Reactionary Modernism. Technology, Culture and Politics in Weimar and the Third Reich. Cambridge University Press: Cambridge; Ash, M.G. (2000): 'Scientific changes in Germany 1933, 1945, 1990: towards a comparison, Minerva: Springer; Szollosi-Janze, M. (ed)(2001): Science in the Third Reich. Berghahn Books: London; Weale, A. (2001): Science and the Third Reich. Channel 4 Books: London.

12 since this is only short paper, we shall mostly restrict ourself to the English-language literature on this, unless it is unvoidable for insights exclusively rendered in German - those texts are listed in the bibliography. 
It is also pertinent to revist major applied and historiographical and ethics-aligned research lines once ever so often (Ash, 1999), especially with the recent rise in far-right discourse in Europe. The discussion will be confined to Nazi-occupied areas here, and not extent to Soviet war crimes during WW2 (Snyder, 2009). As Gutschow (in Schmals, ed., 1997; 2001) observes, the idea of reflection on and probing into ,city visions after Auschwitz' is only at first glance an esoteric question directed towards architects and city planners, because trawling the files and archives testifies to which significant extent National-Socialist visions for ordering space and human activity within it rested on extermination ${ }^{13}$ - indeed it required ethnic segregation, murder (for instance through the „Aktion Reinhard in eastern Poland and the Soviet Union), population eviction, deportation, resettlement ${ }^{14}$ and extermination in the mass shootings and death camps of the „Aktion Reinhard“ in eastern Poland ${ }^{15}$ and the Soviet Union, and then in other death camps such as Stutthof, Majdanek and Auschwitz-Birkenau ${ }^{16}$, as a pre-condition: namely the creation of a ,tabula rasa' of both the Jewish ${ }^{17}$, Sinto and Roma ${ }^{18}$ and the local Polish population ${ }^{19}$ as a precondition for the design of city and space (including rural) in the annexed areas of western Poland ${ }^{20}$

${ }^{13}$ This operationally included the SS, Waffen-SS, the Wehrmacht (army), as well as reserve batallions of the police forces. See Weal, A. (2010): The SS: A New History. Little, Brown \& Company; Knopp, G. et. al. (2003): The SS. A Warning from History. Sutton Publishing: Stroud; Rhodes, R. (2003): Masters of Death: The SS-Einsatzgruppen and the Invention of the Holocaust. Vintage Books; Wette, W. (2006): The Wehrmacht. History, Myth, Reality, chap. 3: 'The Wehrmacht and the Murder of Jews' (translated by Schneider, D.L.). Harvard University Press; Browning, C. (2001): Ordinary Men: Reserve Police Batallion 101 and the Final Solution in Poland. New edition. Routledge.

${ }^{14}$ Spring, T.E. (1999): The Nazi resettlement bureaucracy and the Baltic states of Estonia and Latvia. University of Wisconsin Press: Madison.

15 Arad, Y. (1999): Belzec, Sobibor, Treblinka: The Operation Reinhard Death Camps. New edition. Indiana University Press: Bloomington.

16 Rieger, B. (2007): Creator of Nazi Death Camps: The Life of Odilo Globocnik. Vallentine Mitchell \& Co.; Arad, Y. (1999): Belzec, Sobibor, Treblinka: The Operation Reinhard Death Camps. New edition. Indiana University Press; Caplan, J. \& Wachsmann, N. (eds)(2010): Concentration Camps in Germany. The New Histories. Routledge: London; Rees, L. (2005): Auschwitz. The Nazis and the Final Solution. Ebury Books: London; Dlugoborski, W. \& Piper, F. (eds)(2000): Auschwitz 1940-45: Central Issues in the History of the Camp (5 vols). Oswiecim - Vol 1: Lasik, A. et. al.: The Establishment and Organisation of the Camp; Vol. 2: Iwaszko, T.: The Prisoners: Their Life and Work, Vol. 3: Piper, F.: Mass Murder.

${ }^{17}$ Longerich, P. (2010): Holocaust. The Nazi Persecution and the Murder of the Jews. Oxford University Press; Bergen, D. (2008): The Holocaust: A New History. The History Press; Burleigh, M. (2001): The Third Reich: A New History. New edition. Pan Books; Bankier, D. \& Gutman, I. (eds)(2003): Nazi Europe and the Final Solution: A Reconsideration. Yad Vashem: Jerusalem; Benz, W. (1999): The Holocaust. Columbia University Press; Cesarini, D. (ed)(1994): The Final Solution: Origins and Implementation. Routledge: London; Dwork, D. \& van Pelt, R. (2002): Holocaust: A History. W.W. Norton: New York.; Engel, W. (2000): The Holocaust: The Third Reich and the Jews. Lomgman: New York; Lewy, G. (1999): The Zai Persecution of the Gypsies. New York; Yahil, L. (1990): The Holocaust: The Fate of the European Jewry (trans. Friedma, E. \& Galei, H.). Oxford University Press: New York; Friedlander, S. (2009): Nazi Germany and the Jews: 1933-1945. Harper Perennial: London; Guttman, I. (1990): Encyclopedia of the Holocaust (4 Vols). Macmillan: New York; Laqueur, W. (ed): The Holocaust Encyclopedia. Yale University Press: New Haven; Hilberg, R. (2003): The Destruction of the European Jewry, 3rd ed. Yale University Press: New Haven; Gilbert, M. (1985): The Holocaust. Holt, Rinehart \& Winston; Overy, R. (2010): The Third Reich: A Chronicle. Quercus Publishing. Aly, G. (1999): Final Solution: Nazi Population Policy and the Murder of the European Jewry. London; Smith, H. W. (2008): The Continuities of German History. Nation, Religion and Race across the long Nineteenth Century (esp. chap. 5: 'Eliminatory Racism'). Cambridge University Press; Browning, C. (2004): The Origins of the Final Solution. The Evolution of Nazi Jewish Policy September 1939 - March 1942. William Heinemann: London.

${ }^{18}$ Rose, R. (ed)(2003): The National Socialist Genocide of the Sinto and Roma. Catalogue of the permanent exhibition in thr State Museum of Auschwitz. Dokumentations-und Kulturzentrum Deutscher Sinti und Roma: Heidelberg.

${ }^{19}$ see, for instance, on one notorious regional deportation and 1 morder programme in eastern Poland: Kubica, H. (2006): The Extermination at KL Auschwitz of Poles Evicted from the Zamosz Region in the Years 1942-1943. Auschwitz-Birkenau State Museum: Oswiecim.

20 see, for instance the case of the NS-territorial leader of the annexed are of western Poland, who in an effort to make the Warthegau 'German', introduced numerous cruel policies: Greiser spearheaded an influx of hundreds of thousands of ethnic Germans. He segregated Germans from Poles, and introduced wide-ranging discriminatory measures against the Polish population. He refashioned the urban and natural landscape to make it 'German.' And even more chillingly, the first and longest standing ghetto, the largest forced labour program, and the first mass gassings of Jews in Nazi-occupied Europe were all initiated under Greiser's jurisdiction. Epstein, C. (2010): Model Nazi: Arthur Greiser and the Occupation of Western Poland. Oxford University Press: Oxford. 
And the occupied ,German East', as well as a hunger extermination plan for the Soviet Union's population where the lands were to be colonised („Germanised"). ${ }^{21}$ What remains are often only traces that need to be excavated and interpreted for the local population and further afield in the spirit of remembrance ${ }^{22}$ and reconciliation. ${ }^{23}$ However, the urban political, institutional and resulting „,meaning spaces“ of the urban morphology of an affected town or city may (and perhaps should be expected to) have consequences for contemporary urban development. For instance, Stenning et. al. (2008) explore the notion of institutions shaping the economic and social development of a town - in the case of Oswiecim / Auschwitz both the concentration, death and slave labour camp complex of Auschwitz-Birkenau ${ }^{24}$ and the IG Farben „Buna“ chemical complex ${ }^{25}$ and its post WWII sucessors, and Charlesworth et.al. (2006) explore the contested notion of space and the ,out-of-placeness ' of development post-WWII and post-socialism of both economic and religious infrastructure and activities.

Marcus (2007: 76) suggests that Tuan remind us that ,place is an organised world of meanings', and writes on the relationship of the old and new town of Dachau and the Nazi concentration camp ${ }^{26}$ and the visitor management of the former camp and the place marketing of the modern district city, suggesting that many visitors do not realise that Dachau is also the name for a medieval town (and and an important artist colony in the early 20th century). Marcus suggests that by ,charting the maturation of a city within a city', he, investigates the way the inclusion of the former camp within the modern city of Dachau has resulted in the transfiguring of both entities, redefining their design and social meaning', both internationally and nationally for (the very few) survivors and connected communities, but also for the local contemporary population. ${ }^{27}$

Research by Steinbacher (2005) similarly investigates and problematises the the relationship - both synergic and invested with tensions - of the trinagle of the concentration, slave labour and dealth camp complex, the synthetic rubber chemical works, and the planned Nazi ,model town' of Auschwitz from 1939, underscoring but also taking some issues conceptually with van der Pelt and Dwork's (1996) influential scholarly historiography of Auschwitz from 1270 to the present (including crucially their limited vision of the full integration of the model town of Auschitz „legally“ into the NS German Reich territory, and as a gateway - but outside - occupied Poland as the eastern colonised frontier space).

Testimonies by (Jewish) survivors, such as Josef Jacubowicz (2005), and initiatives by historians and sociologists (Filip, 2005; Trunk, ed, 1979), institutions (such as the Auschwitz Jewish Center), and communities (especially Jewish http://www.jweekly.com/article/full/14447/auschwitz-place-of-memory-vs-oswiecim-a-living-city/ also stress that Auschwitz - Oswiecim ${ }^{28}$ has also been a city / town, and not just a camp complex (Filip, 2005; van Pelt \& Dwork, D, 1996; Steinbacher, 2005; Jacubowicz, 2005). Some other commemorative historical research also makes clear that even whilst the town was under Nazi control there was still support for escapees and inmates, including Jewish, through the local Polish underground resistance (http://ajcf.org/about-the-center/).

\footnotetext{
${ }^{21}$ see Kay, A.J. (2006): Exploitation, Resettlement, Mass Murder: Political and Economic Planning for German Occupation Policy in the Soviet Union, 1940-41. Berhahn Books: New York.

22 including through live and recorded testimonies of both survivors and written leganices of victims who didn't. see, for instance, Smyth, L. (2005): Remembering: Voices of the Holocaust. A New History in the Words of the Men and Women Who Survived. Ebury Press: London; Yad Vashem / Time (2008): Rutka's Notebook. A Voice from the Holocaust. Jerusalem / New York.

${ }^{23}$ Smith, S. D. (2000): Forgotten Places. The Holocaust and the renemants of destruction. Quill Press: Newark. Webber, J. \& Schwarz, C. (2006): Photographing Traces of Memory: A Contemporary View of the Polish Past in Polish Galicia. Galicia Jewish Museum: Cracow; International Youth Meeting Centre / Auschwitz Foundation (2007): The Other Side of the World. 20 Years of the International Youth Meeting Centre in Oswiecim / Auschwitz, $2^{\text {nd }}$ exp. edition, Oswiecim.

${ }^{24}$ see for instance Aly, G. \& Heim, S. (2003): Architects of Annihilation: Auschwitz and the Logic of Destruction. Phoenix.

25 see Sektiewicz, P. (2008): The Histories of Auschwitz IG Farben Werk Camps 1941-1945. Auschwitz Birkemau State Museum: Oswiecim; Wagner, B.C. (2000): IG Auschwitz. Zwangsarbeit und Vernichtung von Haeftlingen des Lagers Monomwitz 1941-1945. K.G. Saur: Munich.

26 see also Marcuse, H. (2001): Legacies of Dachau: The Uses and Abuses of a Concentration Camp, 1933-2001. Cambridge University Press; Caplan, J. \& Wachsmann, N. (eds)(2010): Concentration Camps in Germany. The New Histories. Routledge.

${ }^{27}$ see also Horwitz, G. (2001): In the Shadow of Death: Living outside the Gates of Mauthausen. Free Press: New York.

28 or known as under different names in medieval times due to changing ownership: Ospenchin, 1217; Osvencin, 1280, Hospencin, 1283 Uspencin, 1297, Osswetem, 1290, Oswentim, 1302 


\subsection{Planning ideology: „living space“ and the „General Plan East“}

The ideological direction had been established with Adolf Hitler's „Mein Kampf“ in 1933. This argued that Germans had the „duty“ to conquer „living space“ of ,culturally and racially inferior“ people. ${ }^{29}$ Those visions for the east were new, as large spatial visions and plan had previously only existed with regard to overseas colonies 30. Those colonial and imperialist designs were now now transferred onto Europe and radicalised with all consquences. The aim was not just to take possession of land and resources of a region, and to utilise the resident population as cheap slave labour ${ }^{31}$; rather, the space was to be consquered by design and planning.

This included the deportation and re-settlement of millions of people, with the SS playing a crucial role in this after the occupation of Poland after September 1939 and subsequently further east after the invasion of the Soviet Union ${ }^{32}$, partly because its chief Himmler was ambitions for political authority in the ocupied East European areas, and interpreted his competence as Reichskommissar for the Strengthening of the German Nation (from 7 October 1939 onwards) widely and to include the annexed and occupied Eastern areas, despite Hitler eventually officially restricting them in mid-July 1941 to ,securing through police measures' with other responsibilities officially given to a number of Reichkommissars at the head of the occupation administration (including the western Soviet Union) under the command of Alfred Rosenberg, the Reich Minister for the Occupied Eastern Territories as well as authority for Goering (armed forces) ${ }^{33}$, with Hitler finally announcing in September 1941 that the competences of the Reichskommissar for the Strengthening of the German Nation would now be extended to the occupied Eastern areas. As Longerich (2010: 216) argues, „Himmler had one very significant political motive in making his mission to ,secure through police measure' the Eastern areas as radical as possible and in extending it in the direction of a war of ethnic annihilation: intensifying the mass murder of Poles in the East was a key component of his attempts to extend his competence as Reichskommisar for the Strenthening / Consolidation $=$ Settlement of the German Nation (which he continued to interpret to include as a role as Reichskommisar for the „Germanisation“ of occupied „Living Space“ (,Lebensraum") and the Resettlement for Ethnic Germans (,Volksdeutsche“), as soon as possible to the Eastern areas in order to bring them under the control of the SS via a violent ethnic ,reordering' of the newly conquered ,living space' (Longerich, 2010: 21416). ${ }^{34}$ After the German invasion of Poland on 1 September 1939 and the start of SS and SD (security service) operations in Poland, Heydrich meets SS- Einsatzgruppen leaders to explain Hitler's decision to expel all Jews into non-German eastern territories.

\footnotetext{
${ }^{29}$ For an overview of a whole range of disciplines and scholars who became complicit with the SS and NS ideological project, see Pringle, H. (2006): The Masterplan. Himmler's Scholars and the Holocaust. Fourth Eastate: London.

30 this argument is made with respect to Germany in Olusoga, D. \& Erichsen, C.W. (2010): The Kaiser's Holocaust. Germany's Forgotten Genocide and the Colonial Roots of Nazism. Faber \& Faber: London; Baranowski, S. (2010): German Imperialism, 1871-1945. Cambridge University Press; Smith, W.D. (1989): The Ideological Origins of Nazi Imperialism. New edition. Oxford University Press USA: New York.

${ }_{31}$ see, for instance, Browning, C. (2000): Nazi Policy, Jewish Labour, German Killers. Cambridge University Press; Allen, M. T. (2002): The Business of Slave Labour, and the Concentration Camps. Chapel Hill; Tooze, A. (2007): The Wages of Destruction. The Making \& Breaking of the Nazi Economy. esp. chap. 16: 'Labour, Food, and Genocide'. Penguin.

${ }^{32}$ for a general overview, see Mazower, M. (2008): Hitler's Empire. Nazi Rule in Occupied Europe. Allen Lane.

${ }^{33}$ Hitler's Fuehrer Decrees of 17 July 1939:on the Administration of the Newly Occupied Eastern Areas, and on Securing and Policing the Newly Ocupied Eastern Areas, which conferred responsibility for the 'police' solution of the 'Jewish question' on Himmler (giving him the autority to deploy large-sclae murder squads composed of police and SS brigades), gave Himmler authority to give instructions to the Reichskommissars for carrying out these tasks (involving Rosenberg in 'instructions of a general or fundamental nature or of fundamental importance'), and wich each commissar being assigned a higher SS and police commander.

${ }^{34}$ see also: Manvell, R. \& Fraenkel, H. (2007): Heinrich Himmler. The Sinister Life of the Head of the SS and Gestapo. Greenhill Books; Longerich, P. (2010): Heinrich Himmler: Biographie. Pantheon Verlag (English edition soon from Oxford University Press); Himmler, H. (1939): 'Some Thoughts on the Treatment of the Alian Polulation in the East', in: Noakes, J. \& Pridham, G. (eds)(2001): Nazism 1919-1945: A Documentary Reader, Vol. 3: Foreign Policy, War and Racial Extermination., new ed., pp. 324-6 [reprinted in Gigliotti, S. \& Lang, eds)(2005): The Holocaust. A Reader. Backwell: Oxford.
} 
On the 26 October 1939, Upper Silesia, Pommerania, West Prussia, Poznan and the City of Danzig / Gdansk were incorporated into Germany ${ }^{35}$, with the rest of Nazi-occupied Poland formed into the German vassal state of the „Generalgouvernment" under Hans Frank (who had been appointed as Chief Civilian Officer of Occupied Poland on 12 October 1939). ${ }^{36}$ On 12 November all Jews in areas of Poland annexed by the Nazis are forced into the „Generalgouvernment“, and forced to wear the yellow star (like in Nazi Germany later in September 1941) on the 28th of November (McDonough \& Cochrane, 2008). ${ }^{37}$

The 1943 editition of the Baedecker guidebook to the Generalgouvernment has no mention or any trace of the mass extermination programs beng executed at the same time it was research and edited (principly for the railway tourist), no reference to living Jews(the mostly already in Ghettos), and hardly any trace of a Jewish past in the descriptions of cultural heritage and architecture (Lane, 1997).

To give obtain some insight into the logistical challenges, priorities, and decision-making, it is instructive to both concentrate on some spatial areas and their connections, and to look at key decision makers and implementors.

Against the background of deportation in Germany occuring in public, with the population paying close attention to them and with negative reception from parts of the population to the compulsory identification of Jews in 1941 - particularly in Berlin - led to a police decree announced via the media forbidding the population - under threat of imprisonement in a concentration camp - to have any public contact with Jews. Goebbels, Reich propagana minister, ordered on 23 October 1941 that the deportations were no longer to be mentioned in home propaganda, with anti-semitic propaganda being increased.

Also, as early as May 1940, 2,70 Gypsies had been supported to various parts of the General Government. The local authorities had no idea what to do with the Gypsies: some gave them private accomodation, some used them as forced labourers, some left them to their own devices. The majority of the Gypsies perished as a result of poor conditions, others were executed, some managed to return illegally to the Reich, some somehow survived in the General Government. In early 1941, 5,000 Burgenland (Austrian) Gypsies were deported to Lodz / Litzmannstadt, and were confined to a special, separate section of the Lodz ghetto. The ones who survived the appaling conditions in this camp were murdered in Chelmno death camp in Janauary 1942.

From mid-October 1941 onwards, a total of 25,000 Jews and Gypsies from across the Reich were transported to the already overcrowded Lodz ghetto. At around the same time, the mass murder of indigenous Jews began in the distict of Konim in the southern Warthegau: in late November, in an ,action' lasting several days, 700 Jews were murdered in gas vans in the Bornhagen (Kozminek) camp in the district of Kalisch by the ,Sonderkommando Lange', which had already murdered thousands of inmates in institutions for the mentally ill in the annexed Polish territories in 1939/40 and again in June / July 1941. In 1941, Lange himself had driven himself through the Warthegau to find a suitable location for a stationary killing installation, which he found in Chelmno, upon which Lange's unit started using gas vans to murder Jews there. At first most of the victims were indegenous Jews deported to Chelmno from various ghettos in the Warthegau. From Janauray 1942 onwards, those murdered in Chelmno were primarily inhabitants of the Lodz ghetto - 10,000 in the first wave of deportations between 16 and 29 January. Chaim Rumkowski, who performed his office as Jewish Elder in an autocratic fashion, had managed to halve the figure of 20,000 people demanded by the Nazis, and to keep the selection of this group - undesirable elements', Polish Jews who had recently arrived in the ghetto from the provinces - under his control.

35 see map 2: 'Wartime Poland and its boundaries', p. 144 in Gigliotti, S. \& Land, B.(eds): The Holocaust. A Reader. Blackwell, which shows Auschwitz-Birkenau in annexed East Upper Silesia, and Cracow in the Cracow district of the General government of occupied Poland.

36 see Mazower (2009): map: 'Poland, 1939-1940', and Steinbacher (2005): Map 1: the location of Auschwitz in the GermanPolish border zone', on p. 18, which shows the annexed Easter Zone annexed in 1939 including Oswiecim / Auschwitz, and Cracow in the General Gouvernment of Nazi-occupied Poland. A Polish 14-year old girl, Ruatka Laskier, from a well-to-do Jewish family livingin the middle-sized town of Bedzin / Bendsburg in the area of southern Poland called Zaglembie (in the Eastern zone annexd by Germany in 1939; see Steinbacher: 2005: map on p. 18) with almost half the town's population being Jewish, wrote a diary from 1943 over the period of four month before perishing in the gas chambers in Auschwitz. The illustrated diary (Yad Vashem / Time, Ruatka's Diary. A Voice from the Holocaust, 2008) includes a photo (p. 23) of of the deportation of some of the Jews of Auschwitz / Oswiecim to be settled in Bedzin. After Birkenau, the extermination camp at Auschwitz, became operational in 1943, the journey was reversed, and thousands of Jews from Bedzin were sent there to be murdered.

37 
Over the months that followed, however, it would prove that these ,successes“ were mercilessly exploited by the Nazis to involve the apparatus of the Lodz Jewish council more and more closely in the machinery of deportation. (Longerich, 2010: 290-1; Witte, 1995).

The deportations to Lodz were followed early in 1942 by a further mass deportation of Gypsies with 2,000 from East Prussia being deported to Biaystok. Some members of the group, deemed to be ,assimilated', were sent back to East Prussia in the course of 1942, on condition that they agreed to be sterilised. The rest were deported in the autumn top the Brest-Litowsk ghetto, who inhabitants had been murdered a short time previously. In the sping of 1944, these people were deported to Auschwitz. (Longerich, 2010: 288-9). Soviet Prisoners of War and Soviet civilian slave labourers were equually declared and treated as ,racially inferior ${ }^{6}$ and signed out for destruction (Conolly 1999; Hirschfeld, ed,1986).

Odilo Globocnik, the NS-governor of the district of Lublin (responsible for the liquidation of the Bialystok and Lublin ghettos, and the death camps of Majdanek just outside Lublin and Belzec) demonstrated very early that he was a fervent supporter of Himmler's "General Plan for the East" (Generalplan Ost) to resettle the Lublin area with Volksdeutsch, [ethnic German] immigrants and to extirpate its Jews to that end.

After a visit to Warsaw, in January 1943, Himmler ordered that the ghetto there be destroyed.. Some of those factories that still existed were to be disolved, and the 16,000 workers there to be deported ,to a concentration cap, ideally to Lublin'. The factories actually working for arnaments production were to be ,centralised somewhere in the General Government'. The last deportations in the district of Radom occured in Janauary 1943. When the relocation of production to Lublin at short notice proved impossible, Himmler ordered a concentration camp to be built in the Warsaw ghetto, so that control could be exerted directly over those ghetto inhabitants who had been claimed as workers by the arnaments industry. In the meantime, the SS had once again begun to deport Jews ,unfit for work' from the Warsaw ghetto: between 18 and 22 January around 5,000-6,000 were deported from there to Treblinka death camp and murdered there. In the months that followed concrete preparations were made within the SS empire to bring about the transfer of the Jewish forced labourers. To this end Globocnik negotiated with the SS Business and Administration Head Office (WVHA) to establish the Ostindustrie (industry in the East), which was officially founded in March 1943. This holding company was an attempt to create an arnaments company run by the SS itself, which was to work with Jewish forced labourers and Jewish property. In fact, over the next few months, the Ostindustrie was to maintain various factories in the districts of Lublin and Radom, and deply around 10,000 Jewish workers who were interned in labour camps - though they produced no arnaments, only for the most part simple items of everyday use. (Longerich, 2010: 376-7). In the spring (April and May) of 1943, with the Warsaw ghetto Jewish uprising, the Nazi leadership decided to conclude the ,Final Solution' as quickly as possible, and to no longer take Jewish workers into consideration as a resource - hence the escalation of ,Judenpolitik' in the general Government. Goebbels's diary entry for the 25th of April 1943 reads: it is high time ,for us to remove the Jews as quickly as possible from the General Government'. Himmler stressed in May 1943 to Greifelt, the head of his Central Office for Nationality (Hauptamt fuer Volkstumsfragen), that is was an ,urgent task in the General Gouvernment ... to remove the remaining 300,000 - 400,000 Jwes there'.

Also in May 1943, Fritz Katzmann (commander of the Security Police in Lvov / Lemberg in Galicia) ordered the dissolution of all still existing ghettos in the district of Galicia and had a ,general liquidation plan' prepared to this end The mass murders were carried out with the utmost brutality between the end of May and the end of June 1943; some 80,000 people falling victim to them. Apart from the mass executions, from the end of 1942 until June 1943, some 15,000-25,000 people were deported to Sobibor death camp. Katzmann gave the figure of 434,329 Jews who had been ,resettled' between spring of 1942 and 27 June 1943, with only twenty-one ,Jewish camps' with 21,156 inmates, ,controlled by the SS and police commanders' still in place but ,still being continually reduced' (Longerich, 2010: 378-9)

In the district of Krakau / Cracow, the ghetto in the city of Cracow was the last ghetto to be definitely cleared in March 1943. Those ,fit for work' ended up in the Plaszow forced labour camp, later turned into a concentration camp. Geographers such as Martin Buergener, from Danzig (Gdansk), thought of areas such as the Pripet marshes straddeling the border between Poland and the Soviet Union as a ,grey-dark wilderness' with a series of problems: anarchic waterways, insects, vermin that were uncontrolled, an unstable economy based on hunting in , one of the least developed and most primeval areas of Europe', and a ,population in hopeless anarchy' in what many German scolars considered to be the Urheimat (original home) of the Slavs. 
Contrary to this, the Urgermanen (original Germanic tribes) theory, which had started to gain influence 40 years earlier and had become German conventional wisdom by the 1930s, infered in this context that only in the few spots where vestiges of earlier ,Teutonic' influences remained was there any relief from the ,chaotic' pattern of settlement, only where later German colonist had tilled the soil were signs of an ,exemplary' husbandary to be seen (Blackburn, 2006: 240).

Overall, the NS racial and spatial ideology - as laid out by Hitler in a 1939 Reichstag speech on the ,ethnic reordering of eastern Europe“ - dictated precise planning to facilitate Hitler's belief and edict that the „superior culture“ of the Ayran Germans should dominate politically and economically the ,inferior cultures“, namely the Slaves (including the Poles) - to be robbed of their cultural and intellectual resources and population - and the Jews, to be removed and then progressively to be mass murdered and entirely exterminated in a genozidal ,Final Solution" of which the death camps were but one part of the process, a high intensity and number of victims of mass murder to be attributed to the so-called „Aktion Reinhard“, particularly in the east of occupied Poland and in the Ukraine and Russia.

Himmler, as Reichskommisar for the „Germanisation“ of occupied „Living Space („Lebensraum“) and the Resettlement for Ethnic Germans (,Volksdeutsche“), effected the drafting of altogether five variants of a forced re-modelling of eastern Europe between 1940 and 1943. Together, they constituted the planning complex "General Plan East“. Four of the designs originated from the Reich Commission for the Strengthening of Germandom (RKF) (Koehl, 1957, DFG, 2006), one from the Reich Security Head Office (RSHA). In the centre of the complex was the Head Department Planning and Soil of the RKF, which was directed by Konrad Meyer since 1939.

At the occasion of the opening of the exhibition ,planning and construction in the East“ (Planung und Aufbau im Osten), Meyer held a speech, adressing leading NS-functionaries: Hitler's official deputy Hess, Himmler, Reichsleader Bouhler, Reichsminister Todt (head of the organisation Todt), and the chief of the Reich Security Head Office, Heydrich. (DFG, 2006: 21). At the same event, Himmler explained his settlement plans, with the aid of models, to Rudolf Hess, Hitler's official deputy, on the 20th of March 1941 (DFG, 2006: 24)

In terms of the dimensions of the territory to be planned for, the plans were repeatedly adjusted to the military conquests of the Wehrmacht on the ground, but also pre-empted them. Konrad Meyer argued in an interview with a Polish journalists in 1970 that the plan which was developed under his direction, foresaw the restructuring of the east in the span of 25 years following on from an assumed German victory and the consequential end of WWII. (DFG, 2006).

Eventually, the plans were extended into the „General Settlement Plan“, in which west-European regions were included as German settlement space. The plans were advanced even when facing the probable German military defeat the plans. Next to the RKF and the RSHA there was also a contribution from the Reich Ministry of the Occupied Eastern Territories, the Reich Office for Spatial Planning - under the directorship of Konrad Meyer - as well as Meyer's Institute of Agricultural Sciences and Policy at the University of Berlin. Planners were also able to utilise statistics, maps and literature which had for a long time been assembled by the various organisations of the „Research on the East“ (Ostforschung) and of the ethnographic science as well as from interest and lobby groupings.

The re-ordering of eastern Europe was being planned after strict racial ideological principles. At the beginning of all plan variants stood the „total census“ (Totalerfassung), the „racial appraisal“ (rassiche Durchmusterung) or the „selection“ of the population living in the occupied eastern territories. For the part of the population which could be „re-Germanised“ (Wiedereindeutschungsfähigen) and the „racially welcome alien peoples“ (rassisch erwünschten Fremdvölkischen) a „Germanisation“ (Eindeutschung) or „Re-Nationalisation“ (Rückvolkung) was envisioned. The genocidal murder of the Jewish population was not even mentioned in the plans - is was taken as as pre-condition. According to the plans of the RSHA from Novembver 1941, 31 million Poles, Baltic people, Ukrainians and Belo-Russians were to be deported or murdered, and a further 14 million ,alien people“ were to be utilised for forced labour.

The General Plan East - with its emphasis on a productive rural agricultural space - did place some other emphases: the inhabitants were not to be deported with force, but to be utilised in rural collectives (,Kolchosel“) and resettled. All plan variants were directed towards an agrarian society. 
The aim was a productive agrarian space with a decentralised industry - and settlement structure (Rössler \& Schleiermacher, eds, 1993; Heim, 2006; Madajczyk, ed.,1994). Apart from the radical remodelling of the population structure, the plans were concerned a series of other issues. The transport network was to be newly organised and towns and cities re-constructed or newly designed. The agricultural production fields were to be newly segmentised, the agrarian production increased and the industrial production spaces for manufacturing deembedded. Also, the administrative structure and order was to be entirely re-ordered after the principle of a state and society with the dictatorial leadership (Führerprinzip) and racial hierarchies.

Additionally, the plans comprising the General Plan East envisioned the decimation of the resident population through forced labour and forced de-urbanisation (Entstätterung). The consequence, however, was to murder a major part of the population or to let them starve to death. To Germanise the conquered territories permanently, Meyer planned to settle several million Germans as well as „Germanic“ people from western Europe there - they were meant to „,biologically“ displace the indigenous population. Himmler declared in a speach to senior SS- and police officers in the Ukraine in 1942 that ,the Germanic East up to the Ural mountain range must be ... the germination place of Germanc blood, so that there are in 4 to 5 years ... instead of 120 million 600 million Germanic people.

A comprehensive series of scientific disciplines - funded by the NS institutions of the state and party, but also the scientific institutions such as the Deutsche Forschungs-Gemeinschaft, the Kaiser-Wilhelm-Gesellschaft and the Max-Planck-Society - was involved in these designs and plans: Geology, climatology, transport-, landscape- and urban planning, architecture, statistics, logistics, medicine, vetenary medical science, genetics, agronomy, anthropology and ethnography, sociology, human (eps. political) geography and cartography, political science, law and linguistics.

The scientists who actively part-took in the devising of the General Plan East did not only take notice of the interest of the NS state and contributed their expertise and theoretical and applied knowlede and skills - instead, they were crucially involved in shaping and formulating those interests themselves. Notorious examples would include Otto Reche, director of the institute for race and ethnography at the university of Leipzig, who handed to the SS in September 1939 - driven by self-declared ,academic conscientism“ - his „,maximes for the populationpolitical securing of the German East" for consideration and incorporation of his „racial and race-hygienic considerations"into the offical NS Eastern living space policy, so that his long-standing endeavours in his academic work could find an applied outlet and so that he could consider to have done his duty. Reche wrote in his maximes that ,the present residents of the to be newly handed-over space are, for the most part, entirely useless for the incorporation into the body of the German people. A racial mixing with Germans is to be avoided in all circumstances; this is only to be achieved with the removal of the Poles."

Other examples of scientists and academics who voluntarily offered their service as ,experts for the East“ without being prompted include Eugen Fischer and Fritz Lenz from the Kaiser-Wilhelm-institute for anthropology, human genetics and eugenics, which wrote expertise studies for the new settlement of "German people“ in the ocupied east in the context of the General Plan East, whist their colleague Wolfgang Abel pursued in his studies on Russian POWs already the idea of the liquidation of the Russian people, since they, in his opinion, ,,constituted a threat for the Germans" (DFG, 2006).

Kudlien (1990) explores the the Nazi-German inhumane, asurd and irrational (by way of logic and underlying criteria) response to the birth-rate problem during the Third Reich with regard to „Ostarbeiterinnen“ in Germany in terms of „Eindeutschung“ and procreation or forced sterilisation.

\subsection{The Complicity of Urban Planning and Design: Applied Geographers, Architects and Engineers}

Crucially, as Steinbacher $(2005,2000)$ and others such as Benz (1999) argue, Auschwitz death camp was NOT in the ,unlawful occupied east" undergoing ethnic cleansing and mass murder by mass shootings as well as temporary death camps (such as Sobibor or Treblinka) but was actually under German Nazi Reich jurisdiction with a number of competing authorrities for the newly created region of East Upper Silesia and eventually PURPOSEFULLY incorporated into the territory of the Nazi model and industrial town of Auschwitz.

Furthermore, SS chief Himmler desired to create an ideal National Socialist town, and thought to implement a number of variations on that theme connected with the utility of such a city / town as well - from designing Wolfsburg and Salzgitter as new industrial cities to remodelling medieval Zamosc in eastern Poland (Gutschow, 1997 in Schmals, ed.). 
Himmler was familiar with the work of applied geographer Walther Christaller, who had been commissioned as Himmler's planning consultant for the occupied east, by Himmler planning chief (Prof.) Dr. Konrad Meyer, to devise a rationalised central place functional landscape ordered urban and rural settlement landscape based on an eradication of previous settlement structures. Christaller also had informed Himmler's understanding of the interrelationship of town and countryside and had based his ideas on the medieval balance and symbiosis of the urban / rural connection. (Gutschow, 2001, 1997 in Schmals, ed; Steinbacher, 2005, 2000; DFG, 2006; Heinemann \& Wagner, eds, 2006).

\subsection{The Expansion of Auschwitz town: urban design aspirations and tensions concerning town, camp and slave labour factory}

Breslau / Wroclaw - based Hans Stosberg, appointed by Konrad Meyer as the Auschwitz „Musterstadt“ (model town) architect and also employed to devise designs for re-ordering some of the more small town and rural landscapes of East Upper Silesia, laid out an urban plan for a new Nazi town of 35,000 inhabitants, employing architects such as Klemens Anders in turn. Stosberg also was an admirer of medieval precedents. Space available for the new town was limited by the camp and agricultural area to the west, the Buna plant to the east, and the rivers Sola and Vistula to the south and north. From February 1941 onwards, Stosberg's plan was implemented over a two year period - though not without territorial conflict. Stosberg wanted 115 inhabitants per hectare with three-storey strong terraced dwellings lining major routes with smaller two-storey buildings infilling areas between, creating a strong urban character.

Pressure for available land and position of it caused dissent between Stosberg and Lothar Hartgenstein who had designed the masterplan for the SS settlement. Stosberg felt Hartgenstein's „cosy one-family homesteads set in large gardens“ (effectively the idea of an SS ,garden city“) compromised his denser urban plan. Only as an increasing number of trains transporting Jews arrived at Auschwitz train station was it deemed appropriate or necessary to expose the German town population to what was happening at the camp (with some surviving testimonies by, for instance, a teacher at the secondary high school in town recalling that they were realising what must be happening to the Jews arriving regularly and in large numbers in a one-way traffic), and to relocate the SS ,garden city“. (van Pelt and Dwork, D, 1996; Steinbacher, 2000, 2005).

Parallel to creating the new Nazi German town of Auschwitz as a paradigmal model town on German Reich territory (applying for, and being awarded, central urban improvement grants between 1941 and 1942 in similar fashion to other German cities from Aachen to Zwickau ${ }^{38}$ ) but extending and signifying this model further east into occupied Poland that had not been formally and (ill)'legally' been annexed and incorporated into the Geman Reich, Himmler also planned in the expansion of the existing camp to house 30,000 and the establishment of a new large sub-camp of Birkenau for 100,000 prisoners (on the eradicated Polish village of Brezinka and agricultural fields where also the Bundish (= socialist and non-orthodox and non-Zionist) Jewish local movement did agricultural harvests), as well as negotiating with the industrial mangerial leadership of IG Farben for the establishment of their Buna plant served crucially by slave labour from Birkenau and later the dedicted Auschwitz-Monowitz camp built with slave labour of inmates (on the site of the erdicated Polish village and farms of Monowitz), though also supplied by a smaller contingent of „Reichsdeutsche“ (i.e. from across the Nazi Empire with German nationality) as employed workers. (Steinbacher, 2000, 2005; van der Pelt \& Dwork, D, 1996).

\subsection{Historiographies of Involvement of Built Environment, Planning and Geography professions in the Nazi conquest of space - reconstructions for the future ?}

There was undoubtably prestige, financial rewards and future career advancements to be gained for professionals at all scale and levels - from the urban ,units“ designed to contain 20,000 inhabitants, markets towns of 5,000 population ideal size, to individual building design of crematoria and gas chambers, the engineering and design developments of the double-muffled furnances and ovens for human corpses by Topf \& Söhne, the Zyklon B gas (supplied by Degesch but manufactured in the Dessau works for sugar and chemical industry, and the Kali works in Cologne) delivery system and air extraction systems contained within these buildings and infrastructures.

\footnotetext{
${ }^{38}$ see table in Luken-Isberner, F. , p. 134, in Smals, K.M. (ed)(1997): Vor 50 Jahren .. auch die Raumplanung hat eine Geschichte ! IRPUD: Dortmund.
} 
Likewise, administration experts like Heinrich Bütefisch, responsible for the SS in the Auschwitz-Monowitz for organsising the slave labour IG Farben needed in their chemicals production were found guilty at the Nuremberg Tribunals for Nazi war and crime against humanity defendants organised by the Allies ${ }^{39}$.

\subsection{Professional Ethics post-Auschwitz?}

It is interesting to look through a biographical, institutional and societal (here: state and corporate) lense at the conduct and consequences for professionals during but also post-WWII. Three examples of careers ${ }^{40}$ and decisions, and the societal response are selected for prompting a reflection below.

Heinich Bütefisch was punished at Nuremberg for organising slave labour for the SS with a verdict of six years of imprisonement, but released early in 1951. He was subsequently appointed to a supervisory board directorship of the Ruhrkohle coal and energy concern, and received the Cross of Merit from the Federal Republic of Germany in 1964, which he agreed to hand back after protests to pre-empt an official cancellation of the award. http://www.zyklon-b.info/menschen/buetefisch.htm

Prof. Konrad Mayer was recalled to a Professorial Chair at the University of Hannover in Agricultural Sciences, served on a national advisory commission again post WWII and was awarded some grants from the German Research Council (DFG) again (DFG, 2006).

Kurt Gerstein, an NSDAP party member since May 1933 who rebelled against the NS take-over of the churches and turned into an opposition church-connected dissident who was incarcerated in 1936 and again in 1938, joined the Weapons-SS as an officer on 1941 to take on Hitler's NS regime from the inside and to try and expose it. He became the head of their department of hygiene technology, and was hence directly tasked with the sourcing of the poison gas Zyklon B, whereby no warning substance was added and the usual distributing companies of Testa and Heli were cut out by Degesch and brought directly to the Auschwitz and Sachsenhausen death camps. Gerstein visited in an official capacity the death camps of the „Aktion Reinhard“, and therefore gathered firsthand witnessing of mass gassings and informed foregin diplomats as well as senior official church representatives abroad about the crimes against humanity in his „Gerstein eyewitness report“. After WW II he died as a French POW in still uncertain circumstances.

\section{0}

We would strongly argue that there is a need, including in higher education ${ }^{41}$, and a professional and societal gain - not just for a country such as Germany having to come to terms with, atone for and recall and remember its NSera - for a reflection on professional, institutional and organisation ethics, as otherwise the role of disciplines such as architecture, design, engineering and planning could well be, in a setting of a totalitarian / fascist and undemocratic society, become a vehicle for total moral breakdown; where the infrastructure is a „machine“ (to borrow le Corbusier's phrase ,a housing is a machine for living in“) not for living in but for the opposite: the removal of freedom and dignity, and ultimately life. We consider - much like Smals (1997) - ,spatial planning (and associated disciplines and professions) not as a bundle of value-free and a-historical instruments and techniques, but in a most crucial dimension also an expression of societal politics, an embodiment of human civilisation and the creation of a social and physical community and infrastructure in which context processes of societal civilization can be achieved or those of a de-civilisation can be founded and pronounced. We need a democratically founded and organised spatial and urban planning which can contribute significantly to the further civilisation process of modern societies.

\footnotetext{
${ }^{39}$ see, for instance, Owen, J. (2007): Nuremberg. Evil on Trial. Headline Review: London; http://www.zyklonb.info/menschen.htm

${ }^{40}$ see also Troeger, J. (ed): 1986): Hochschule und Wissenschaft im Dritten Reich. Campus: Frankfurt a.M.; Hachtmann, R. (2008): 'Forschen fuer Volk und "Fuehrer". Wissenschaft im Dritten Reich', in: Suess, D. \& Suess, W. (eds): Das “Dritte Reich”. Eine Einfuehrung. Pantheon Verlag. After 1945: Frei, N. (ed)(2002): Karrieren im Zwielicht: Hitlers Eliten nach 1945. Frankfurt a.M.

${ }^{41}$ c.f Shimoni, G. (ed)(1991): The Holocaust in University Teaching. Pergamon Press: London; Jacobs, S. L. et. al. (2004):

Teaching About the Holocaust: Essays by College and University Teachers. Greenwood Press. London.
} 
This can and should also draw from the dark episodes of the disciplines to inform learning and reflection for the future, across social, disciplinary, professional and national barriers and borders ${ }^{42}$.

\subsection{Bibliography (including key German texts)}

Allen, M. T. (2002): The Business of Slave Labour, and the Concentration Camps. Chapel Hill.

Allen, M.T. (1997) The Banality of Evil Reconsidered: SS Mid-Level Managers of Extermination Through Work. In: Central European History 30 (02), pp. 253 - 294.

Aly, G. \& Heim, S. (2003): Architects of Annihilation: Auschwitz and the Logic of Destruction. Phoenix.

Ash, M. G. (1999): Scientific Changes in Germany 1993, 1945, 199: Towards a Comparison. Minerva 37, pp. 329-354.

Bassin, M. (1987): Race and space. The conflict between German „Geopolitik" and national socialism. In: Political Geography Quarterly 6, pp. 115-134

Bauman, Z. (1989): Modernity and the Holocaust. Polity Press: Bristol

Baxtor, I. (2008): The Commandant: Rudolf Höss, the creator of Auschwitz. Maverick House. Dublin.

Blackbourn, D. (2006): The Conquest of Nature. Water, Landscape and the Making of Modern Germany (chap. 5:'Race and Reclamation'). Jonathan Cape: London.

Browning, C.R. (2000): Nazi Policy, Jewish Workers, German Killers. Cambridge University Press: Cambridge.

Burleigh, M. (1997): Ethics and Extermination: Reflections on Nazi Genocide. Cambridge University Press.

Caplan, J. \& Wachsmann, N. (eds)(2010): Concentration Camps in Germany. The New Histories. Routledge.

Cesarini, D. (2006): Eichmann: His Life and Crimes. New edition. Vintage: London.

Charlesworth, A; Stenning, A.C.; Guzik, R.; Paszkowski, M. (2006): ,Out of place“ in Auschwitz ? Contested development in post-war and post-socialist Oswiecim', Ethics, Place \& Environment 9(2), pp. 149-172.

Conolly, J. (1999): ,Nazis and Slavs: From Racial Theory to Racial Practice‘, Central European History 32(1), pp. 1-33.

Denecke, D. (2006): Ideology in the planned order upon the land: the example of Germany, chap. 14 in Baker, A.R.H. \& Biger, G. (eds)(2006): Ideology and Lanscape in Historical Perspective. Essays on the Meaning of some Places in the Past. Wiley.

Deutsche Forschungsgemeinschaft (2006): Wissenschaft. Planung. Verteribung. Der Generalplan Ost der Nationlasozialisten. Eine Austellung der Deutschen Forschungsgemeinschaft. DFG: Bonn / Berlin. http://www.dfg.de/pub/generalplan/index.html

Ebbinghaus, A. and Roth, K.H. (1999): "Vorläufer des 'Generalplans Ost.' Eine Dokumentation über Theodor Schneiders Polendenkschrift vom 7. Oktober 1939“.

Fahlbusch, M.; Rössler, M. A.; Siegrist, D. (1989): ,Conservatism, ideology and geography in Germany 19201950‘, Political Geography Quarterly 8, pp. 353-367.

Filip, L. (2005): Juden in Oswiecim. 1919 - 1941. Verlag Scienta: Oswiecim;

Friedlander, S. (2009): Nazi Germany and the Jews: 1933-1945. Harper Perennial: New York / London.

Gilbert, M. (2009): The Routledge Atlas of the Holocaust. $4^{\text {th }}$ ed. Routledge: London.

Gutman, Y. et. al. (eds)(1998): Anatomy of the Auschwitz Death Camp. United States Holocaust Museum: Wahington D.C.

Gutschow, N. (2001): Ordnungswahn. Architekten planen im , eingedeutschten' Osten 1939-1945. Berlin.

Hagen, J. (2008): ,Parades, Public Spaces, and Propaganda: The Nazi Culture Parades in Munich', Geografiska Annaler: Series B, Human Geography 90:4, pp. 349-367.

Hagen, J. (2006) Preservation, Tourism, and Nationalism: Rothenburg as the Jewel of the German Past. Ashgate Publishing: Aldershot, United Kingdom and Burlington

Hagen, J. and Ostergren, R. (2006): ,Architecture, Spectacle, and Place during the Nuremberg Party Rallies: Projecting a Nazi Vision of Past, Present, and Future', Cultural Geographies 13:1, pp. 1-25.

Hagen, J. (2004) ,The Most German of Towns: Creating an Ideal Nazi Community in Rothenburg ob der Tauber', Annals of the Association of American Geographers 94:1, 207-227.

\footnotetext{
${ }^{42}$ Ambrosewicz-Jacobs, J. \& Jacobs, M. (eds)(2005): Why Should We Teach About the Holocaust ? $2^{\text {nd }}$ edition Institute of European Studies, The Jagiellonian University / ODIHR / OSCE: Cracow. Ambrosewicz-Jacobs, J. \& Oleksy, K. (eds)(2008): Remembrance. Awareness. Responsibility. Auschwitz-Birkenau State Museum: Oswiecim; AmbrosewiczJacobs, J. (ed)(2009): The Holocaust. Voices of Scholars, Centre for Holocaust Studies. Auschwitz-Birkenau State Museum. 12
} 
Heibner, H. u.a. (1958): ,Der Generalplan Ost', in: Vierteljahrhefte fuer Zeitgeschichte 6, pp. 281-325.

Heim, S. (2006): Expansion policy and the role of agricultural research in Nazi Germany. Minerva 44(3), pp. 267284.

Heinemann, I. \& Wagner, P. (eds)(2006): Wissenschaft - Planung - Vertreibung: Neuordnungskonzepte und Umsiedlungspolitik im 20. Jahrhundert. Franz Steiner Verlag: Stuttgart.

Herb, G. (1997): Under the Map of Germany. Nationalism and Propaganda 1918-1945. London, New York.

Herbert, U. (ed.)(2000): National Sozialist Extermination Policies. Berghahn Books: New York / Oxford.

Hilberg, R. (1995): The Destruction of the European Jews (three volumes). Holmes and Meier: Taneck, NJ.

Hirschfeld, G. (ed)(1986): Policies of Genocide. Jews and Soviet Prisoners of War. Harper Collins: London.

Hoess, R., Broad, P. \& Kremer, J.P. (2006): KL Auschwitz seen by the SS. Auschwitz-Birkenau State Museum: Osiecim.

Jacubowicz, J. (2005): Auschwitz is also a city. A Survivor of the Shoah tells his story. Thiemo Graf Verlag.

Kay, A.J. (2006): Exploitation, Resettlement, Mass Murder: Political and Economic Planning for German Occupation Policy in the Soviet Union, 1940-41. Berhahn Books: New York.

Koehl, R.L. (1957): RKFDV: German Resettlement and Population Policy, 1935-1945: A History of thr Reich Commission for the Strengthening of Germandom. Harvard University Press: Cambridge, MA.

Kost, K. (1989): ,The conception of politics in political geography and geopolitics in Germany until 1945, Political Geography Quarterly 8, pp. 369-385.

Kubica, H. (2006): The Extermination at KL Auschwitz of Poles Evicted from the Zamosc Region in the Years 1942-1943 (transl.: Zbirohowski-Kosica, W.). Auschwitz-Birkenau State Museum: Oswiecim.

Kudlien, F. (1990): ,The German response to the birth-rate problem during the Third Reich', Contiuity and Change 5(2), pp. 225-247.

Lane, N. (1997): ,Tourism in Nazi-Occupied Poland: Baedecker's Generalgouvernment ${ }^{\circ}$, East European Jewish Affairs 27:1, pp. 45-56.

Longerich, P. (2010): Holocaust. The Nazi Persecution and Murder of the Jews. Oxford University Press: Oxford.

Longerich, P. (2010): Himmler: Eine Biographie. Pantheon Verlag [English edition forthcoming from Oxford University Press]

Madajczyk, C. (1977): Zamojszczyzna - Sonderlaborium SS. Eine Sammlung polnischer und deutscher Dokumente aus der Zeit der nationalsozialistischen Besetzung. Warsaw.

Madajczyk, C. (ed.)(1994): Vom Generalplan Ost zum Generalsiedlungsplan: Dokumente. Munich: Saur.

Marcus, A. (2007): ,Beautiful Dachau's Contested Urban Idenity“, chap 4 in: Marcus, A. \& Neumann, D. (eds): Visualizing the City. Routledge: New York.

Mazower, M. (2008): Hitler's Empire. Nazi Rule in Occupied Europe. Allen Lane.

Nelson, R.L. (ed)(2009): Germany, Poland, and Colonial Expansion to the East. 1850 Through to the Present. Palgrave Macmillan: London.

Piper, F. \& Swiebocka, T. (eds)(2005): Auschwitz. Nazi Death Camp (translation: Selvage, D.). AuschwitzBirkenau Death Camp: Oswiecim.

Rees, L. (2005): Auschwitz. The Nazis and the ,Final Solution'. BBC Books:London.

Rose, G. (1993): ,Architecture after Auschwitz' (review of a discussion betwenn Robert van der Pelt and Carrol William Westfall), Assemblage 21, pp. 63-69.

Rose, R. (ed.)(2003): The National Socialist Genocide of the Sinti and Roma. Catalogue of the permanent exhibition in the State Museum of Auschwitz. Dokumentations- und Kulturzentrum Deutscher Sinti und Roma: Heidelberg.

Rössler, M. (1989): ,Applied geography and area research in Nazi society: central place theory and planning, 1933 to $1945^{\prime}$, Environment \& Planning: Series D 7, pp. 419-431.

Rössler, M. (2001): ,Geography and Area Planning under National Socialism', in: Margit Szöllösi-Janze, M. (ed): Science in the Third Reich. Berg Publishers: Oxford.

Rössler, M. \& Schleiermacher, S. (eds)(1993): Der Generalplan Ost. Hauptlinien der nationalsozialistischen Planungs- und Vernichtungspolitik. Akademie Verlag: Berlin.

Rieger, B. (2007): Creator of Nazi Death Camps: The Life of Odilo Globocnik. Vallentine Mitchell \& Co. 
Rutherford, P.T. (2007): Prelude to the final solution: the Nazi program for deporting ethnic Poles, 1939-1941. University of Kansas Press.

Schwarz, C. (2006): Photographing Traces of Memory. A Contemporary View of the Jewish Past in Galicia, 2nd ed. (with introductory texts by Webber, J.). Galicia Jewish Museum: Krakow.

Sandner, G. (1988): ,Recent advances in the history of German geography 1918-1945: a progress report for the Federal Republic of Germany', Geographische Zeitschrift 76, pp. 102-133

Setkiewicz, P. (2008): The Histories of Auschwitz IG Farben Werk Camps 1941-1945. Auschwitz-Birkenau State Museum: Oswiecim.

Smals, K. (ed)(1997): Vor 50 Jahren ... auch die Raunplanuing hat eine Geschichte !. Dortmunder Beiträge zur Raumplanung 80 (Blaue Reihe). Fakultät fuer Raumplanung, Universität Dotmund: Dortmund.

Steinbacher, S. (2005): Auschwitz. A History. Penguin: London.

Steinbacher, S. (2000): ,Musterstadt' Auschwitz. Germanisierungspolitik und Judenmord in Ostoberschlesien. Munich.

Steinweis, A. E. (1994): ,Ideology and infrastucture: German area science and planning for the Germanization of Eastern Europe, 1939-1944. ', East European Quarterly 28, 335-347.

Stenning, A. et. al. (2008): ,A tale of two institutions: Shaping Osiecim-Auschwitz', Geoforum, 39 (2008), pp. 401-413.

Smith, S.D. (2000): Forgotten Places. The Holocaust and the Remains of Destruction. Quill \& Beth Shalom Holocaust Centre: Newark, Lincolshire.

Smyth, L. (2005): Remembering: Voices of the Holocaust. Ebury Press: London.

Snyder, T. (2009): The Holocaust: The Ignored Reality. The New Yorker, 16 July 2009.

Spring, T.E. (1999): The Nazi resettlement bureaucracy and the Baltic states of Estonia and Latvia. University of Wisconsin Press: Madison.

Swiebocka, T. (ed.)(2008): The Architecture of Crime. The Security and Isolation System of the Auschwitz Camp. Auschwitz-Birkena State Museum: Oswiecim. (translation: Brand, W.)

Swiebocka, T. (ed.)(2001): The Architecture of Crime. The „Central Camp Sauna“ in Auschwitz II- Birkenau. Auschwitz-Birkenau State Museum: Oswiecim (translation by Brand, W.)

Tooze, A. (2006): The Wages of Destruction. The Makuing and Breaking of the Nazi Economy. Routledge: London.

Van der Pelt, R. J. \& Dwork, D. (1996): Auschwitz. 1270 to the Present. Yale University Press: New Haven, CT and London.

Wasser, B. (1993): Himmler's Raumplanung im Osten. Der Generalplan Ost in Polen 1940-1944. Birkhaeuser Verlag: Basel.

Weiss, S.P. (2010): The Nazi Symbiosis. Human Genetics and Politics in the Third Reich. Chicago University Press: Chicago.

Willems, S. (2000): Der entsiedelte Jude. Albert Speers Wohnungsbaupolitik fuer den Berliner Hauptstadtbau. Berlin.

Witte, P. (1995): ,Two Decisions Concerning the"Final Solution to the Jewish Question": Deportatiosn to Lodz and Mass Murder in Chelmno“, Holocaust and Genocide Studies 9(3), pp. 318-345. 